\title{
PEMBENTUKAN KARAKTER MELALUI PEMBELAJARAN SASTRA BERBASIS EKOLOGIS DALAM KUMPULAN CERITA RAKYAT NUSANTARA
}

\author{
Hasrul Rahman ${ }^{1)}$, Denik Wirawati ${ }^{2)}$, Julivan Nur Ahmad Sidiq ${ }^{3)}$ \\ ${ }^{1), 2), 3)}$ PBSI, FKIP, UAD, Jl Ahmad Yani, Tamanan, Banguntapan Bantul, Yogyakarta \\ ${ }^{1)}$ hasrul.rahman@pbsi.uad.ac.id, ${ }^{2)}$ denik@pbsi.uad.ac.id
}

\begin{abstract}
ABSTRAK
Pembelajaran sastra selalu memiliki berbagai macam metode yang dapat digunakan dalam proses kegiatan belajarnya. Melalui pembelajaran sastra, pendidik dituntut untuk lebih kreatif sekaligus peka dalam memilih materi yang menarik untuk disampaikan. Para pendidik saat ini kurang memperhatikan hal tersebut. Para pendidik hanya terpaku pada target-target yang akan disampaikan sesuai materi dan RPP yang sudah ada sebelumnya, tanpa berpikir lebih jauh mengenai hal-hal lain yang dapat dijadikan sumber pembelajaran. Padahal di era seperti sekarang ini, banyak hal yang bisa dimanfaatkan melalui kegiatan pembelajaran sastra untuk membentuk karakter bangsa. Pembentukan karakter dapat dilakukan dengan cara memilih buku-buku sastra yang kaitannya dengan masalah kekinian, misalnya saat ini sedang banyak terjadi kebakaran hutan, sungai yang dipenuhi sampah, dan lain-lain. Problematika tersebut tentunya dapat dikaitkan dengan materi ajar yang akan disampaikan. Dengan mengedepankan kepekaan terhadap hal-hal yang sedang terjadi, tentunya proses pembelajaran sastra akan berjalan dengan baik. Salah satunya mangaitkan pembelajaran sastra berbasis ekologis dengan kumpulan cerita rakyat. Selama ini para pendidik saat mengajarkan materi cerita rakyat hanya sebatas pada isi cerita dan tokoh-tokoh yang terlibat di dalamnya sehingga metode seperti ini sudah seharusnya dicermati kembali agar pembelajaran sastra kedepannya akan lebih menarik dan menyenangkan. Dengan adanya pembelajaran sastra berbasis ekologis peserta didik dituntut untuk menemukan pesan yang berkaitan dengan hubungan antara manusia dan lingkungannya dalam cerita tersebut. Hal ini tentunya sangat bermanfaat bagi peserta didik agar mereka tahu tentang pentingnya menjaga lingkungan.
\end{abstract}

Kata kunci: Pengajaran Sastra, Ekologi, Cerita rakyat nusantara

\section{PENDAHULUAN}

Sastra merupakan salah satu bagian penting yang tak bisa terpisahkan dalam kehidupan. Melalui sastra orang akan lebih memahami wujud keindahan bahasa pengarang dalam sebuah tulisan. Sastra selalu menawarkan sebuah karya yang mengolaborasikan kehidupan nyata dengan fiksi. Dari sinilah sastra dapat dibangun dengan wujud yang menarik perhatian pembacanya. Perkembangan sastra yang sangat pesat menjadikan daya taritersendiri bagi pembacanya maupun para peneliti 
Hasrul Rahman ${ }^{1)}$,Denik Wirawati ${ }^{2)}$, Julivan Nur Ahmad Sidiq ${ }^{3)}$ : Pembentukan Karakter Melalui Pembelajaran Sastra Berbasis Ekologis dalam Kumpulan Cerita Rakyat Nusantara Website : https://jurnal.umj.ac.id/index.php/penaliterasi Email : penaliterasi@umj.ac.id

untuk mengetahui lebih jauh makna yang terkandung di dalamnya. Keanekaragaman sosial-budaya yang ada di Indonesia sangat memengaruhi terciptanya karya-karya baru dibidang sastra. Sastra di Indonesia tidak melulu hanya membahas sastra dalam bentuk tulisan saja, tetapi ada juga yang disebut sebagai sastra lisan.

Kelahiran sastra lisan maupun tulisan memiliki arti penting dalam perkembangan dunia kesusasteraan di Indonesia. Munculnya sastra sangat dipengaruhi oleh lingkungan sekitar. Dengan adanya karya sastra, orang akan lebih mengenal suatu peristiwa maupun budaya masyarakat di suatu wilayah. Salah satunya melalui karya sastra lisan yang ada di Indonesia. Hal ini senada dengan pendapat Isnanda (2015: 175) yang mengatakan bahwa Indonesia sebagai negara yang terdiri atas berbagai suku bangsa yang memiliki banyak ragam budaya tercermin dalam gaya dan pola hidup masing-masing daerah. Kebudayaan merupakan ciri khas suatu bangsa yang melambangkan jati diri bangsa tersebut yang harus dijaga dan dilestarikan oleh segenap warga negara Indonesia. Budaya yang ada di Indonesia mempunyai keunikan yang berbeda-beda di setiap daerah. Dengan kehadiran sebuah karya sastra di tengah-tengah kehidupan manusia dengan memuat berbagai pesan-pesan kehidupan sehingga dapat dijadikan sebagai sarana pendidikan bagi manusia di tengah-tengah kehidupan yang sedang menghadang berbagai kemajuan pada sendi-sendi kehidupan yang memerlukan kontrol diri bagi setiap individu dalam mengadopsi pengaruh perubahan yang datang sehingga tradisi leluhur (budaya) tidak mudah terkikis seiring kemajuan zaman Indonesia sebagai negara yang terdiri atas berbagai suku bangsa yang memiliki banyak ragam budaya tercermin dalam gaya dan pola hidup masing-masing daerah.

Banyaknya sastra lisan yang ada di Indonesia berarti mengindikasikan bahwasannya kebudayaan di Indonesia sangatlah banyak. Dengan adanya sastra lisan tersebut, masyarakat Indonesia maupun Internasional menjadi tahu selukbeluk daerah atau budaya di daerah setempat. Sastra lisan yang ada di Indonesia menjadi daya tarik tersendiri bagai para pelancong untuk mendatangi daerah tersebut. Kelahiran sastra lisan yang dibalut dengan kebudayaan tentunya memiliki tujuan tersendiri, yakni berupa pesan-pesan kehidupan bagi pembacanya. Hal inilah yang membuat karya sastra menjadi sebuah informasi yang menarik bagi para guru maupun siswa untuk diteladani sehingga pembaca akan lebih tahu tentang nilai-nilai pendidikan karakter yang tertuang di dalam cerita tersebut. Seperti halnya yang terdapat dalam cerita rakyat nusantara.

Pendidikan karakter yang terdapat dalam Kumpulan Cerita Rakyat Nusantara tentunya sangat menarik untuk dimaknai lebih dalam, terutama pada sisi ekologisnya. Menurut Setyawan dkk. (2017: 199) mengatakan bahwa pendidikan karakter merupakan salah satu pilar penting yang turut berperan dalam penyelenggaraan pendidikan. Akan tetapi, dalam praktiknya pendidikan karakter masih kerap dikesampingkan dibandingkan pendidikan kognitif (kecerdasan intelektualitas) yang dijadikan 
Hasrul Rahman ${ }^{1)}$,Denik Wirawati ${ }^{2)}$, Julivan Nur Ahmad Sidiq ${ }^{3)}$ : Pembentukan Karakter Melalui Pembelajaran Sastra Berbasis Ekologis dalam Kumpulan Cerita Rakyat Nusantara Website : https://jurnal.umj.ac.id/index.php/penaliterasi Email : penaliterasi@umj.ac.id

orientasi capaian utama. Pendidikan karakter yang terdapat di dalam kumpulan cerita rakyat tentunya memiliki pesanpesan yang menarik untuk masyarakat, baik secara moral maupun sosialnya. Lebih lanjut Widianti (2017: 2) mengatakan bahwa pengajaran sastra memiliki peran bagi pemupukan kecerdasan siswa dalam semua aspek, termasuk moral. Melalui apresiasi sastra, misalnya kecerdasan intelektual, emosional, dan spiritual siswa dapat dilatih serta dikembangkan. Siswa tidak hanya terlatih untuk membaca saja, tetapi harus mampu mencari makna dan nilai-nilai dalam sebuah karya sastra. Dalam buku Kumpulan Cerita Rakyat Nusantara tentunya juga memiliki banyak sekali pesan untuk pembacanya. Hal yang akan dibahas oleh peneliti ialah berkaitan dengan sastra ekologi dalam cerita rakyat

\section{METODE PENELITIAN}

Metode dalam penelitian ini adalah metode kualitatif deskriptif. Metode kualitatif adalah prosedur penelitian yang menghasilkan kata-kata tertulis maupun lisan dari orang-orang dan prilaku yang dapat diamati (Moleong, 2007: 3). Sumber data diambil dari Kumpulan Cerita Rakyat Nusantara. Penelitian ini menggunakan sudut pandang ekologi sastra untuk mengkaji Kumpulan Cerita Rakyat Nusantara. Teknik pengumpulan data yang digunakan ialah teknik catat, simak, dan catat. Kemudian teknik analisis yang digunakan ialah teknik analisis interaktif, yang terdiri dari reduksi data, sajian data, dan penarikan simpulan (Miles dan Huberman, 2007: 20). nusantara. Cakupan ekologi tentunya sangatlah luas seperti yang dikatakan oleh Mu'in (2013: 298) bahwasannya alam telah menjadi bagian dari sastra. Ini terbukti dengan tidak sedikitnya sastrawan, khususnya dari kalangan penyair, yang menggunakan diksi hutan, laut, pohon, dan lain-lain dalam karya mereka. Namun seiring perkembangan, sastra telah banyak mengalami perubahan, begitu juga alam. Kedua elemen yang tak terpisahkan ini seakan selalu berjalan beriringan. Sastra tempo dulu adalah wajah alam masa lalu dan sastra sekarang adalah wajah alam masa kini. Sastra membutuhkan alam sebagai inspirasinya, sedang alam membutuhkan sastra sebagai alat konservasinya. Lebih lanjut Endraswara (2016:18) mengatakan bahwa dengan kajian ekologi sastra, akan dapat terungkap bagaimana peran sastra dalam memanusiakan lingkungan.

\section{HASIL DAN PEMBAHASAN}

Setiap karya sastra yang tercipta selalu memiliki tujuan tertentu untuk pembacanya. Tujuan tersebut dapat diaplikasikan melalui pembelajaran sastra. Dengan adanya pengajaran sastra, nilai dari karya sastra yang ada dapat tersampaikan dengan baik kepada siswa. Baik itu yang bersifat moral maupun yang lainnya. Menurut Ismawati (2013:30) secara garis besar pengajaran sastra dapat dipilah menjadi dua bagian,yakni jangka pendek dan panjang. Tujuan jangka pendek, yakni supaya siswa lebih memahami proses kreatif dari terciptanya karya tersebut. Di samping itu siswa dapat menanya, memberi tanggapan atas apa yang sudah dibaca dari karya sastra tersebut, sedangkan Jangka panjangnya adalah supaya siswa dapat 
Hasrul Rahman ${ }^{1)}$,Denik Wirawati ${ }^{2)}$, Julivan Nur Ahmad Sidiq ${ }^{3)}$ : Pembentukan Karakter Melalui Pembelajaran Sastra Berbasis Ekologis dalam Kumpulan Cerita Rakyat Nusantara Website : https://jurnal.umj.ac.id/index.php/penaliterasi Email : penaliterasi@umj.ac.id

memaknai dengan baik terhadap nilai-nilai pendidikan yang terdapat di dalam karya tersebut.

Pengajaran sastra berbasis ekologis tidak kalah penting dengan nilai pendidikan yang lainnya dalam karya sastra. Memaknai ekologis berarti memahami keadaan lingkungan yang membahas hubungan manusia dengan lingkungannya. Lingkungan menjadi faktor penting dalam kehidupan manusia. Dengan lingkungan yang sehat hidup akan lebih bermanfaat. Hubungan antara manusia dengan lingkungan dalam karya sastra sangatlah erat, itu terbukti dengan adanya karya sastra yang mengaitkan dengan lingkungan sekitarnya. Salah satunya yang terdapat dalam Kumpulan Cerita Rakyat Nusantara.

Selama ini para pendidik lebih banyak menceritakan tentang asal-usul suatu daerah atau hanya mendongeng terkait cerita rakyat tersebut tanpa membahas unsur-unsur lain yang terkandung di dalamnya, misalnya unsur ekologinya. Hal in tentunya harus diubah agar proses pembelajaran lebih menarik. Dengan menyampaikan unsur ekologi dalam karya sastra, siswa akan lebih tahu sejak dini mengenai pentingnya menjaga alam dan lingkungan sekitar supaya tetap terjaga. Sepertinya halnya yang terdapat dalam cerita rakyat dari Provinsi Sumatra Utara yang berjudul Asal Mula Danau Toba, cerita rakyat Sumatra Barat yang berjudul Maling Kundang, cerita rakyat Lampung yang berjudul Buaya Perompak, dan masih banyak lagi yang tentunya dapat dijadikan penguatan untuk menumbuhkan sikap keteladanan bagi manusia yang lainnya. Berikut kutipan dalam cerita rakyat dari Provinsi Sumatra Utara yang berjudul Asal Mula Danau Toba.

"Selain mengolah tanah di ladangnya, kadang-kadang lelaki itu pergi memancing ikan ke sungai

yang berada tak jauh dari rumahnya.

Setiap kali dia memancing, mudah saja ikan didapatnya karena di sungai yang jernih itu banyak sekali ikan. Ikan hasil pancingannya dia masaka untuk dimakan"(Cerita Rakyat Nusantara; 8-9).

Sungai menjadi mata pencaharian untuk sebagian orang sehingga manusia wajib untuk menjaganya tetap bersih, agar ekosistem di dalam air pun tetap ada. Kutipan tersebut menjadi sebuah nasihat yang berkaitan dengan ekologi. Hal-hal semacam inilah yang perlu disampaikan kepada peserta didik agar dapat menanamkan pengetahuannya sejak dini. Dengan mengetahui informasi seperti kutipan di atas, setidaknya akan mengurangi dampak lingkungan karena ulah manusia yang tidak bertanggung jawab.

Para sastrawan sebenarnya sudah menuliskan pesan terkait dengan lingkungan sejak zaman dahulu melalui proses kreatifnya. Akan tetapi, permasalahannya para pendidik belum menyampaikan secara detail mengenai hal tersebut. Akibatnya, banyak peserta didik hanya memahami pada sebatas isi cerita tersebut tanpa memahami pesan yang disisipkan penulis dalam cerita tersebut. Berikut kutipan yang berkaitan dengan ekologi dalam cerita rakyat Sumatra Barat yang berjudul Maling Kundang.

"Di tempat itu suami Mande Rubayah mengubah mata pencaharian, dari tukang perambah hasil hutan sekarang menjadi nelayan ikan" (Cerita Rakyat Nusantara; 30).

Kutipan tersebut memiliki sebuah pesan kepada pembacanya, bahwasannya 
Hasrul Rahman ${ }^{1)}$,Denik Wirawati ${ }^{2)}$, Julivan Nur Ahmad Sidiq ${ }^{3)}$ : Pembentukan Karakter Melalui Pembelajaran Sastra Berbasis Ekologis dalam Kumpulan Cerita Rakyat Nusantara Website : https://jurnal.umj.ac.id/index.php/penaliterasi Email : penaliterasi@umj.ac.id

lingkungan alam baik itu hutan, sungai, dan laut merupakan sebuah titipan yang harus dijaga agar tidak punah maupun tercemar oleh ulah manusia. Hutan berfungsi sebagai sumber oksigen bagi semua makhluk hidup, sedangkan sungai dan laut merupakan sumber pencaharian bagi kehidupan manusia. Sudah seharusnya manusia dapat hidup berdampingan dengan alam. Kutipan di atas dapat dijadikan sebagai materi ajar bagi siswa-siswi agar mereka lebih memahami tentang pentingnya menjaga lingkungan alam sejak dini. Dengan pemahaman tersebut, maka setidaknya lingkungan alam akan terjaga dengan baik.

Saat ini lingkungan menjadi hal yang paling banyak disorot. Dengan bertambahnya penduduk di Indonesia tentunya yang paling berdampak ialah lingkungan. Para pendidik harus terus memberikan penjelasan secara detail terhadap dampak-dampak yang timbul karena kerusakan lingkungan terhadap anak didiknya. Guru dapat mengambil materi ajar melalui cerita rakyat yang ada di masing-masing daerah. Seperti halnya pembuangan sampah sembarangan di sungai yang mengakibatkan kebanjiran dan terhentinya aliran sungai karena penumpukan sampah. Seharusnya hal-hal seperti ini bisa dihindari melalui sosialisasi maupun penanaman pengetahuan kepada siswa sejak dini. Banyak hal yang bisa dijadikan sebagai sumber pembelajaran salah satunya pada cerita rakyat Provinsi Lampung yang berjudul Buaya Perompak. Berikut kutipannya.

"Aminah mulai teringat kejadian mengapa ia berada di dalam goa bersama buaya itu. kemarin ia berada di tepi sungai, baru saja membuang sampah. Tiba-tiba sesuatu yang besar menyambar dirinya. Ia seperti tenggelam ke dasar sungai. Ia tak sadarkan diri, berada di dalam goa bersama Buaya Perompak" (Cerita Rakyat Nusantara; 68).

Kutipan tersebut menunjukkan adanya pesan yang ditujukan untuk pembacanya. Pesan tersebut berupa larangan membuang sampah sembarangan. Dalam kutipan di atas menjelaskan bahwasannya siapapun yang membuang sampah sembarangan akan membuat penghuninya murka dan orang tersebut bisa celaka. Manusia merupakan makhluk Tuhan yang diberi anugrah akal, sudah seharusnya bisa berfikir lebih jauh mengenai dampak-dampak yang serius jika melakukan kesalahan yang sama terus menerus. Dampak lingkungan akan sangat berbahaya jika manusia memiliki sikap acuh tak acuh terhadap lingkungan alam. Di sinilah sastra ikut andil dalam menjaga lingkungan alam.

\section{KESIMPULAN}

Sumber materi yang dapat
digunakan dalam pengajaran sastra sangatlah luas. Sumber tersebut dapat diambil dari berbagai karya sastra yang ada di Indonesia. Salah satunya dapat diambil dari Kumpulan Cerita Rakyat Nusantara. Banyak hal yang masih perlu digali lagi untuk menemukan sesuatu yang baru dari dalam cerita rakyat tersebut. Dalam aspek ekologisnya, terdapat berbagai macam bentuk hubungan antara manusia dengan lingkungan alam yang dapat dijadikan sebagai refrensi pembelajaran sastra. Refrensi ini dapat menjadi pemantik dalam meningkatkan kualitas peserta didik dalam memahami lingkungannya melalui pengajaran sastra. Pada prosesnya, dalam pengajaran sastra membutuhkan kepekaan dan kejelian dalam memilih materi yang 
Hasrul Rahman ${ }^{1)}$,Denik Wirawati ${ }^{2)}$, Julivan Nur Ahmad Sidiq ${ }^{3)}$ : Pembentukan Karakter Melalui Pembelajaran Sastra Berbasis Ekologis dalam Kumpulan Cerita Rakyat Nusantara Website : https://jurnal.umj.ac.id/index.php/penaliterasi Email : penaliterasi@umj.ac.id

kekinian. Para pendidik dituntut untuk sekreatif mungkin dalam mengolah atau memilih materi yang kekinian. Sebab karya sastra dapat menjadi sebuah sarana yang paling logis untuk menyampaikan pesan bagi pembacanya terkait dengan isu-isu yang sedang terjadi. Salah satunya isu lingkungan. Di sinilah peran sastra berfungsi untuk mengangkat martabat bangsa ke arah yang lebih baik serta dapat berpikir modern.

\section{REFERENSI}

Endraswara, Suwardi. 2016. Metodologi Penelitiam Ekologi Sastra, Konsep, Langkah, dan Penerapannya. Jakarta: Buku Seru.

Ikranegara, Tira. Kumpulan Cerita Rakyat Nusantara. Jakarta: Media Pustaka.

Ismawati. Esti. 2013. Pengajaran Sastra. Yogyakata: Penerbit Ombak.

Isnanda, Romi. 2015. Peran pengajaran sastra dan budaya dalam pembentukan karater siswa sekolah dasar. Gramatika. Vol 1, no i2, hal 174-182.

Miles, B. Mattew dan Michael A. Huberman. 2007. Analisis Data Kualitatif. Terjemahan oleh Tjejep Rohendi Rohidi. Jakarta: UI Press.

Moleong, Lexy J. 2007. Metode Penelitian Kualitatif. Bandung: Rosdakarya.

Mu'in, Fatchul. 2013. Ekokritisme: Kajian Ekologis dalam Sastra. Procedings of Literature and Nation Character Building, Banjarmasin: November 6-9 2013. Hal. 295-306.
Setyawan, Arief dkk. 2017. Muatan Pendidikan Karakter Dalam Cerita Rakyat Di Pacitan. Jurnal Pendidikan Karakter. VII, 2, hal 199-211.

Widianti, Ande Wina. 2017. Kajian Ekologi Sastra Dalam Kumpulan Cerpen Pilihan Kompas 2014 Di Tubuh Tarra Dalam Rahim Pohon. Diksatrasia. Vol 1, No 2, hal 1-9. 